\title{
Evaluation of Nutrient, Antinutrient and Phytochemical Properties of Noni Fruit (Morinda citrifolia) Concentrate, Pulp, and Seed
}

\author{
Nkeiruka M. Oly-Alawuba and Amaka A. Iwunze \\ Department of Nutrition and Dietetics, College of Health Sciences, Imo State University, Owerri 23483, Nigeria
}

\begin{abstract}
The study assessed the nutrients, anti-nutrients and phytochemical properties of noni concentrate, pulp, and seed. Noni plant is a small evergreen tree, used for both medicinal purposes and for food. Six kilograms (6 kg) of matured, ripe noni fruit (Morinda citrifolia), was harvested by hand picking, from Green Health Farm, Imo State, Nigeria. It was divided into three equal parts, for the purposes of sample preparation and analysis. Noni pulp: One portion of the noni fruit sample was cleaned, washed and drained to remove debris and thereafter, was spread on a clean tray and allowed to air dry, at room temperature. This practice encouraged further ripening and softening of the fruit. The seeds were then removed and the fruit crushed, to extract the pulp. The pulp was packaged in an air tight container and kept in the fridge for further analysis. Noni concentrate: The second portion of the noni fruit samples was cleaned, washed and allowed to air dry on a raised table, under room temperature. With the aid of a juice collection box, the juice was extracted and stored in a clean dry container for further analysis. Noni seed: The third portion of the noni fruit samples was cleaned, washed, to remove debris and thereafter, was crushed by hand to select the seed. The seeds were separated from the pulp by a strong spray of water, and then washed to further remove pulp on the seed. The seeds were dried for 2 days in open air and further oven dried and then grounded to a fine powder and packaged for analysis. The results of the proximate composition of noni seed, pulp and concentrate showed significant difference $(p<0.05)$ in the protein content of the seed, pulp and concentrate. The crude protein increased from $0.02 \%$ to $4.53 \%$. The seed had the highest protein content (4.53\%). There was significant difference $(p<0.05)$ in the moisture content of the seed, pulp and concentrate. The moisture content of the seed (8.27\%) was lower than that of pulp (92.55\%) and concentrate (88.38\%). The crude fiber contents of the seed, pulp and concentrate were all significantly different $(p<0.05)$. The seed had $28.7 \%$ crude fiber value while pulp and concentrate had $0.03 \%$ and $1.95 \%$ respectively. The ash content of noni seed was significantly $(p<0.05)$ higher (3.07\%), in respect to pulp (1.06\%) and concentrate (0.79\%). The crude fat values of the pulp (3.98\%) and concentrate (2.99\%) were higher than the seed (2.00\%) and all were significantly different $(p<0.05)$. Noni seed had the highest nutrient, anti-nutrient and Vitamin B2 content. The high fiber content and phenolic compound found in noni seed make it a functional food.
\end{abstract}

Key words: Noni fruit, nutrient, anti-nutrient and phytochemical.

\section{Introduction}

Noni fruit shown in Fig. 1, is the common name for Morinda citrifolia and is also called Indian mulberry, ba ji tian, nono or nonu, cheese fruit, and nhau in various cultures throughout the world [1]. Noni plant is a small evergreen tree found growing in open coastal regions at sea level and in forest areas up to about 1,300 feet above sea level [2]. The mature noni fruit

Corresponding author: Nkeiruka M. Oly-Alawuba, $\mathrm{PhD}$, research fields: community/public health nutrition \& experimental foods. displayed in Fig. 1, has a foul taste and odour [3]. Noni was first discovered and used by man long before recorded history in Southeast Asia and the subcontinent when ancient Indian Medicine men began examining the natural world to find plants good not only for food but to treat disease and otherwise benefit their health $[4,5]$. It has been reported to have a broad range of health benefits for cancer, infection, arthritis, diabetes, asthma, hypertension, and pain [6]. Noni was a traditional remedy used to treat broken bones, deep cuts, bruises, sores, and wounds. AOAC [7] described a wide range of potential indications for noni juice, 


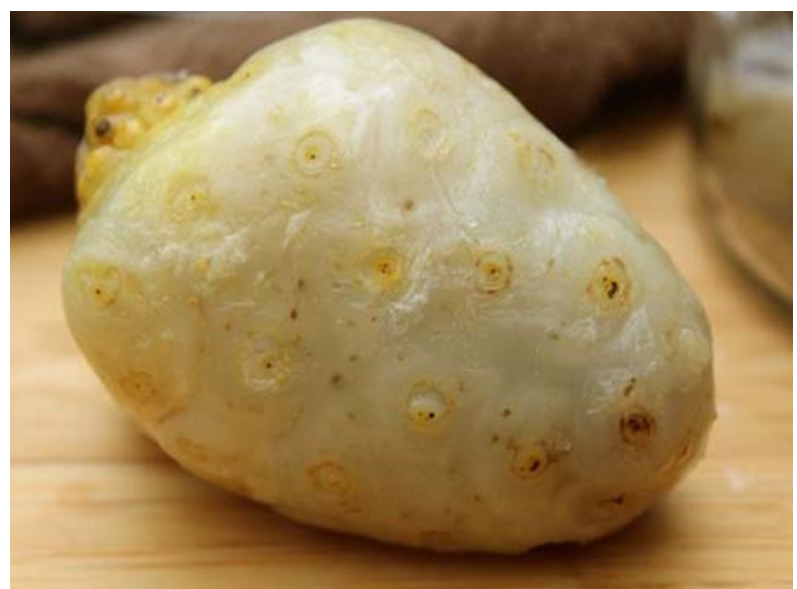

Fig. 1 Noni fruit (Morinda citrifolia).

including high blood pressure, menstrual cramps, hypertension, gastric ulcers, sprains, injuries, mental depression, atherosclerosis, blood vessel problems, drug addiction, relief of pain and many others. Various publications have shown that it can be used to relieve different diseases. Scientists and medical professionals have shown increased interest in this field as they recognize the true health benefits of this plant [8].

Noni juice has relatively lower amounts of macronutrients but high in micronutrients [9]. Research shows that phytochemicals are able to reduce the oxidative damage to our cells that causes various diseases like cancer [10]. Noni fruit juice contains a particular phytochemical called xeronine. Xeronine enhances enzyme activities and protein structure [11]. It is presence in noni fruit juice that is known for its ability to relieve pain in the body [12]. Noni juice is also packed with proxeronine, the precursor of xeronine. It is activated in the large intestine, where it is absorbed by the cells of the body [13].

\subsection{Anthraquinones (Damnacanthol)}

These are important antiseptic and antibacterial plant chemicals found in noni juice, which have been proven to be effective in killing pre-cancer cells [14]. They stimulate the immune response to cancer by activating the body's T-cells, which are the body's "cancer killers" [15].

\subsection{Scopoletin}

This is an important chemical component of noni juice with wonderful health benefits which are attributed to its anti-inflammatory, anti-histamine, antifungal, and antibacterial properties [16]. It regulates serotonin which makes the body feel good hormone to ward off feelings of anxiety and depression. It also binds to melatonin to regulate sleep, hunger and body temperature [16].

\subsection{Low Glycemic Index}

Noni juice has a 3:1 ratio of carbohydrates to fiber which helps balance blood sugar levels. The juice concentrate is said to contain a third more polysaccharides than aloe vera, which is one of the highest polysaccharide-rich super foods known in the plant world [17]. The polysaccharides in noni are believed to enhance white blood cell efficiency and boost immune system functions [14].

\section{Materials and Methods}

\subsection{Collection and Preparation of Samples}

Six kilograms (6 kg) of matured, ripe noni fruits (Morinda citrifolia), were harvested by hand picking, from Green Health Farm, Imo State, Nigeria. The fruits were divided into three equal portions, for the purposes of sample preparation and analysis. 


\subsubsection{Noni Pulp}

One portion of the fruit samples was cleaned, washed and drained to remove debris and thereafter, spread on a clean tray and allowed to air dry, at room temperature. It was kept at room temperature to ripen fully and soften, after which the seeds were removed and the fruit was crushed to extract noni pulp. The pulp was packaged in an air tight container and kept in the fridge for further analysis. The flowchart for the Noni pulp preparation is shown in Fig. 2.

\section{Matured ripe noni fruit}

\section{Harvested}

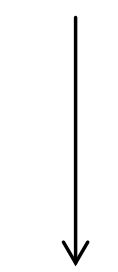

Washed

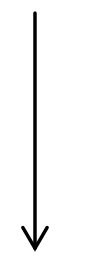

Air dried

Deseeded matured ripe noni

\section{Crushed fruit to extract pulp}

Fig. 2 Flow chart for the preparation of noni pulp.

\section{Noni pulp}


2.1.2 Noni Concentrate

The second portion of the samples was cleaned, washed and allowed to air dry on a raised table, under room temperature. With the use of a juice collection box, the concentrate was extracted and stored in a clean dry container for further analysis. The flowchart in Fig. 3 shows the steps involved in the preparation of noni concentrate.

\section{Matured ripe noni fruit}

Harvested

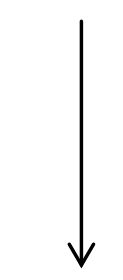

\section{Washed}<smiles>C1CCCCC1</smiles>

Air dried<smiles>C1CCCCC1</smiles>

Placed in a juice collection box

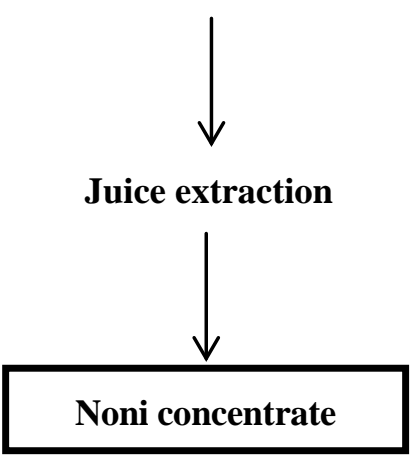

Fig. 3 Flow chart on the preparation of noni concentrate. 


\subsubsection{Noni Seed}

The third portion of the noni fruit samples was cleaned, washed, to remove debris and thereafter, was crushed by hand to select the seed. The seeds were separated from the pulp by a strong spray of water, and then washed to further remove pulp on the seed. The seeds were dried for 2 days in an open air and further dried for another 2 days at an ambient temperature and grounded to fine powder and packaged for analysis. Fig. 4 shows the flowchart description of how to prepare noni seed flour, for further use.

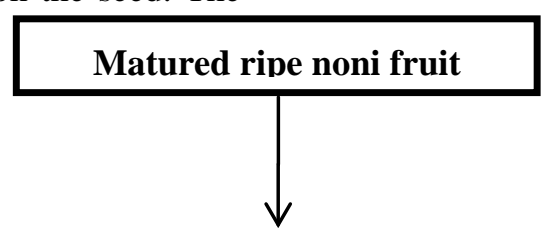

Harvested by hand
$\downarrow$
Washed
$\downarrow$

\section{Crushed by hand}

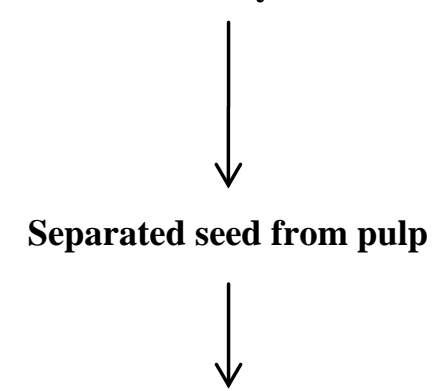

\section{Further washed}<smiles>C=[V]</smiles>

Sun dried<smiles>C=[V]</smiles>

Grounded<smiles>C=[V]</smiles>

Packaged<smiles>[AsH2][AsH2]</smiles>

Grounded noni seed in powdered form

Fig. 4 Flow chart on the preparation of noni seed. 
The data obtained from different analyses were subjected to various statistical methods which included simple descriptive mean, standard deviation and analyses of variance (ANOVA), while Turkey's test was used to separate the means from the samples examined using SPSS 20.0.

\section{Results}

The proximate composition of noni seed, pulp and concentrate displayed in Table 1, showed significant difference $(p<0.05)$ in the protein content. The crude protein increased from $0.02 \%$ to $4.53 \%$. The seed had the highest protein content $(4.53 \%)$. There was significant difference $(p<0.05)$ in the moisture content of the seed, pulp and concentrate. The moisture content of the seed $(8.27 \%)$ was lower than that of pulp (92.55\%) and concentrate (88.38\%). The crude fibre content of the seed, pulp and concentrate was all significantly different $(p<0.05)$.

The seed had $28.7 \%$ crude fibre value while pulp and concentrate had $0.03 \%$ and $1.95 \%$ respectively.

The moisture found in noni pulp and concentrate in this study was higher than $84 \%$ and $82 \%$ for pineapple and soursop juices respectively, as reported by Akubor and Egbekun [18].

Moisture content of fruit is a function of its quality which determines its freshness at harvest or storage duration before analysis [19]. It is also a function of its shelf-life stability.

The ash content of noni seed was significantly ( $p<$ $0.05)$ higher $(3.07 \%)$ than that of pulp (1.06\%) and concentrate (0.79\%).

The low ash observed in the pulp and concentrate as shown in Table 1, could be attributed to their high fluid content which supports the report by Nwokocha and Akobundu [20], that low ash is the most common in fruit juices.

The values of the carbohydrate content were all significantly different $(p<0.05)$.

The carbohydrate content of the pulp was observed to be the lowest. The low carbohydrate in the pulp was not surprising because juices are generally known to be low in carbohydrate. The carbohydrate content of Cola parchycarpa juice (4.9\%) was higher than that of noni pulp. Noni fruit contains carbohydrates and dietary fibre in moderate amounts [21].

The crude fat contents of the pulp (3.98\%) and concentrate (2.99\%) were higher than the seed $(2.00 \%)$ and all were significantly different $(p<0.05)$.

Table 2 showed the vitamin properties of noni seed, pulp and concentrate, vitamin A value of noni seed (0.37 mg/100 g) was significantly lower than the concentrate $(0.435 \mathrm{mg} / 100 \mathrm{~g})$ and pulp $(0.53 \mathrm{mg} / 100 \mathrm{~g})$ at $(p<0.05)$. Noni has a positive effect on the skin as it is a rich source of vitamin C. Daily dose of noni juice has proven to be beneficial in treating several skin problems like acne, pimples, rough and dry skin, and even dark spots on the skin [22]. As an antioxidant, noni juice will provide nourishment to the cells, tissues and organs. It will also fight free radicals and reverse the adverse effects of aging and pollution.

Vitamin $B_{2}$ value of the seed shown in Table 2, was higher $(0.27 \mathrm{mg} / 100 \mathrm{~g})$ in relation to the pulp $(0.22$ $\mathrm{mg} / 100 \mathrm{~g})$ and concentrate $(0.08 \mathrm{mg} / 100 \mathrm{~g})$, at $(p<$ $0.05)$.

The anti-nutrient properties of noni seed, pulp and concentrate, revealed that Tannin content of noni seed $(0.27 \%)$ was significantly higher than the pulp $(0.22 \%)$ and concentrate $(0.23 \%)$.

Table 4 shows the anti-nutrient properties of noni seed, pulp and concentrate. The result revealed that Tannin content of noni seed $(0.27 \%)$ was significantly higher than the pulp $(0.22 \%)$ and concentrate $(0.23 \%)$.

Tannins are known to affect the digestive tracts and their metabolites are toxic [23]. Besides the precise toxic amount of tannins to cause depression in human is not known, but the values obtained for these phenolic substances in this study are quite low and may not cause any depression.

The alkaloid values as displayed in Table 4, showed significant difference between the seed (12.42\%), pulp (4.27\%) and concentrates (4.38\%). 
Table 1 Proximate composition of noni seed, pulp and concentrate.

\begin{tabular}{lllllll}
\hline Sample & Protein (\%) & $\begin{array}{l}\text { Moisture content } \\
(\%)\end{array}$ & Crude fibre (\%) & Ash (\%) & Fat (\%) & $\begin{array}{l}\text { Carbohydrate } \\
(\%)\end{array}$ \\
\hline Seed & $4.53^{\mathrm{a}} \pm 0.006$ & $8.27^{\mathrm{c}} \pm 0.025$ & $28.70^{\mathrm{a}} \pm 0.010$ & $3.07^{\mathrm{a}} \pm 0.015$ & $2.00^{\mathrm{c}} \pm 0.010$ & $55.45^{\mathrm{a}} \pm 0.035$ \\
Pulp & $0.04^{\mathrm{b}} \pm 0.001$ & $92.55^{\mathrm{a}} \pm 0.285$ & $0.03^{\mathrm{c}} \pm 0.005$ & $1.06^{\mathrm{b}} \pm 0.025$ & $3.98^{\mathrm{a}} \pm 0.020$ & $2.36^{\mathrm{c}} \pm 0.280$ \\
Concentrate & $0.002^{\mathrm{c}} \pm 0.001$ & $88.38^{\mathrm{b}} \pm 0.270$ & $1.95^{\mathrm{b}} \pm 0.030$ & $0.79^{\mathrm{c}} \pm 0.030$ & $2.99^{\mathrm{b}} \pm 0.020$ & $5.88^{\mathrm{b}} \pm 0.245$ \\
LSD & & 0.57 & - & 0.08 & - & 0.54 \\
\hline
\end{tabular}

Values are means \pm SD of three replications. Means with different superscript letters in the columns are significantly different at $5 \%$ level of significance.

Table 2 Vitamin content of noni seed, pulp and concentrate.

\begin{tabular}{llll}
\hline Sample & Vit. A (mg/100 g) & Vit. B2 (mg/100 g) & Vit. C (mg/100 g) \\
\hline Seed & $0.37^{\mathrm{c}} \pm 0.008$ & $0.27^{\mathrm{a}} \pm 0.10$ & $1.80^{\mathrm{b}} \pm 0.006$ \\
Pulp & $0.53^{\mathrm{a}} \pm 0.015$ & $0.22^{\mathrm{b}} \pm 0.002$ & $2.38^{\mathrm{a}} \pm 0.027$ \\
Concentrates & $0.435^{\mathrm{b}} \pm 0.005$ & $0.08^{\mathrm{c}} \pm 0.003$ & $2.11^{\mathrm{c}} \pm 0.027$ \\
LSD & - & - & -
\end{tabular}

Values are means \pm SD of replications. Means with different superscript letters in the columns are significantly different at $5 \%$ level of significance.

Table 3 Mean values for mineral content (mg/100 $\mathrm{g}$ ) of noni seed, pulp and concentrate.

\begin{tabular}{llllll}
\hline & $\begin{array}{l}\text { Potassium } \\
(\mathrm{mg} / 100 \mathrm{~g})\end{array}$ & $\begin{array}{l}\text { Manganese } \\
(\mathrm{mg} / 100 \mathrm{~g})\end{array}$ & $\begin{array}{l}\text { Calcium } \\
(\mathrm{mg} / 100 \mathrm{~g})\end{array}$ & $\begin{array}{l}\text { Sodium } \\
(\mathrm{mg} / 100 \mathrm{~g})\end{array}$ & $\begin{array}{l}\text { Magnesium } \\
(\mathrm{mg} / 100 \mathrm{~g})\end{array}$ \\
\hline Seed & $0.26^{\mathrm{c}} \pm 003$ & $0.37^{\mathrm{c}} \pm 0.05$ & $0.19^{\mathrm{c}} \pm 0.02$ & $0.40^{\mathrm{a}} \pm 0.01$ & $0.11^{\mathrm{c}} \pm 0.01$ \\
Pulp & $11.85^{\mathrm{a}} \pm 0 ; 06$ & $0.82^{\mathrm{a}} \pm 0.04$ & $0.35^{\mathrm{a}} \pm 0.04$ & $0.20^{\mathrm{b}} \pm 0.03$ & $3.95^{\mathrm{a}} \pm 0.05$ \\
Concentrate & $8.07^{\mathrm{b}} \pm 0.07$ & $0.51^{\mathrm{b}} \pm 0.03$ & $0.23^{\mathrm{b}} \pm 0.03$ & $0.11^{\mathrm{c}} \pm 0.01$ & $2.55^{\mathrm{b}} \pm 0.04$ \\
LSD & 0.30 & 0.12 & 0.03 & - & 0.08 \\
\hline
\end{tabular}

Values are means \pm SD of three replications. Means with different superscript letters in the columns are significantly different at $5 \%$ level of significance.

Table 4 Anti-nutrient content of noni seed, pulp and concentrate.

\begin{tabular}{llll}
\hline Sample & Tannin (\%) & Alkaloid (\%) & Flavonoids (\%) \\
\hline Seed & $0.27^{\mathrm{a}} \pm 0.006$ & $12.42^{\mathrm{a}} \pm 0.006$ & $8.55^{\mathrm{a}} \pm 0.015$ \\
Pulp & $0.22^{\mathrm{c}} \pm 0.002$ & $4.27^{\mathrm{c}} \pm 0.015$ & $2.97^{\mathrm{b}} \pm 0.020$ \\
Concentrates & $0.23^{\mathrm{b}} \pm 0.002$ & $4.38^{\mathrm{b}} \pm 0.020$ & $2.57^{\mathrm{c}} \pm 0.035$ \\
LSD & - & - & 0.08
\end{tabular}

Values are Means \pm SD of three replication. Means with different superscript letters in the columns are significantly different at $5 \%$ level of significance.

The results of the flavonoids showed that the seeds (8.55\%) were significantly higher than the pulp (2.97\%) and concentrate $(2.57 \%)$ at $(p<0.05)$.

The high flavonoid obtained from the seed of noni, agrees with the findings of FAO/WHO [24], who reported that natural colouring in plant based foods with antioxidants, anti-inflaming and diverted effects is due to flavonoids as observed in the seeds.

Research shows that phytochemicals are able to reduce the oxidative damage to our cells that causes various diseases like cancer [25].
Noni contains compounds like saponins. These properties make it beneficial for diabetic patients [26].

Table 3 shows the mineral composition of noni seed, pulp and concentrate.

The pulp sample showed an appreciable mineral content. The potassium content of the pulp (11.8 $\mathrm{mg} / 100 \mathrm{~g}$ ) was significantly $(p<0.05)$ higher than the concentrate $(8.07 \mathrm{mg} / 100 \mathrm{~g})$ and seed $(0.26 \mathrm{mg} / 100 \mathrm{~g})$. Potassium appears to be the most abundant mineral in processed noni fruit puree.

This is also in line with mineral analyses performed 
for Cambodian noni fruit juice and raw noni fruit by Shovic and Whister [27] and in Australia by Chuhieng et al. [28] and Mortan [29].

The manganese value, was significantly different ( $p$ $<0.05)$ among the noni seed $(0.37 \mathrm{mg} / 100 \mathrm{~g})$, pulp $(0.82 \mathrm{mg} / 100 \mathrm{~g})$ and concentrate $(0.51 \mathrm{mg} / 100 \mathrm{~g})$. The pulp was significantly higher $(p<0.05)$ than the seed and concentrate. The seed had the lowest value.

There was a significant difference $(p<0.05)$ between the calcium content of the pulp $(0.35 \mathrm{mg} / 100$ g), seed $(0.19 \mathrm{mg} / 100 \mathrm{~g})$ and concentrate $(0.23 \mathrm{mg} / 100$ g).

The sodium content of the seed $(0.40 \mathrm{mg} / 100 \mathrm{~g})$ was significantly $(p<0.05)$ higher than the pulp $(0.20$ $\mathrm{mg} / 100 \mathrm{~g})$ and concentrate $(0.11 \mathrm{mg} / 100 \mathrm{~g})$. The concentrate had the lowest sodium content (0.11 $\mathrm{mg} / 100 \mathrm{~g})$. Plants and fruits are generally poor in sodium, apart from some vegetable species [30]. The sodium content of the noni pulp $(0.20 \mathrm{mg} / 100 \mathrm{~g})$ was close to the content of Cambodian juice $(0.22 \mathrm{mg} / 100$ g). Sodium, with potassium, controls the water balance of the body [30].

The pulp had the highest magnesium value (3.95 $\mathrm{mg} / 100 \mathrm{~g})$ and was significantly $(p<0.05)$ higher than the seed $(0.11 \mathrm{mg} / 100 \mathrm{~g})$ and concentrate $(2.55 \mathrm{mg} / 100$ g). Magnesium is present in practically all tissues. It plays a role in the transport of energy. Human magnesium consumption is often lower than that recommended 330-420 mg/day [31]. In extreme magnesium deficiency, craps, tetary crises, tiredness and insomnia can be observed. Magnesium also has a role in the prevention of cardiovascular diseases [32].

\section{References}

[1] Wang, M. Y., West, B. J., Jensen, C. J, Nowicki, C. D., Palu, A., and Gary, A. 2002. "An Edible and Medicinal Tropic Plant-Morinda citrifolia L. (Noni).” University of Illinois College of Medicine, Department of Pathology, 1601 Parkview Avenue, Rockford, IL 61107, USA; Department of R\&D, Morinda Inc., Provo, Utah 84606, USA.

[2] Pawlus, A. D., Keller, B. N., and Kinghorn, W. J. 2005. "An Anthraquinone with Potent Quinone
Reductase-Inducing Activity and Other Constituents of the Fruits of Morinda citrifolia (Noni).” Journal of Natural Products 68 (12): 1720-2.

[3] Tolle, S., Lander, V., and Winterhalter, P. 2011. "Authentication of Fruit Juices Derived from Morinda citrifolia (Noni).” In Progress in Authentication of Food and Wine, Chapter 18, Vol. 1081, pp. 249-58.

[4] Heinicke, R. M. 2005. "The Pharmacologically Active Ingredient of Noni." Bulletin of the National Tropical Botanical Garden 15: 10-4.

[5] Saba. 2016. "28 Best Benefits of Noni Juice for Skin, Hair, and Health.” Accessed May 14, 2017. https://www.Stylecraze.com/articles/benefitsofnoni-juicefor-skin-hairandhealth.

[6] Daniluk, J. 2012. "Phytochemicals Important to Health.” Accessed April 1, 2017. https://www. juliedaniluk.com.

[7] AOAC.2000. Official Methods of Analysis, 16th ed. USA: Association of Official Analytical Chemists, pp. 233-4.

[8] AOAC (Association of Official Analytical Chemists). 2000. Official Method, 979.09, Protein (Crude) in Animal Feed. Gaithersburg, MD: AOAC International.

[9] AOAC (Association of Official Analytical Chemists). 2000. "Official Method, 960.39, Fat (Crude) in Meat.” In Official Methods of Analysis of the Association of Official Analytical Chemists, 17th ed. Gaithersburg, MD: AOAC International.

[10] James, C. S. 1995. The Analytical Chemistry of Food. New York: Chapman and Hall, 14, 21-7.

[11] Kirk, and Sawyer. 1998. Pearson's Composition and Analysis of Foods, 7th ed. U.K.: Longman Scientific and Technical Publisher, 708.

[12] Okwu, D. E., and Ndu, C. U. 2006. "Evaluation of the Phytonutrients, Minerals and Vitamin Content of Some Varieties of Yam (Discoreaspp).”S. Mol. Med. Adv. Sci. 12: 199-203.

[13] Boham, A. B., and Kalipai, D. C. 1994. "Flavonoid and Condensed Tannins from Leaves of Hawaiian, Vaccinium, Vaticulum and Vicalycinium.” Pacific Science 48: 458-63.

[14] Obadoni, B. O., and Ochuko, P. O. 2001. "Phytochemical Studies and Comparative Efficacy of the Crude Extracts of Some Homeostatic Plants in Edo and Delta States of Nigeria.” Global J. Pure Appl. Sci. 8: 203-8.

[15] Pearson, D. 1976. The Chemical Analysis of Food, 7th ed. Burgh Scot: Church Hill, Livingstone, p. 499.

[16] Singh, D. R. 2012. “A Review of the Scientific Validation for Morinda citrifolia L. (Noni) Nutritional and Therapeutic Properties." Journal of Diabetes and Endocrinology 3 (6): 77-9.

[17] Akubor, P. I., and Egbekun, M. K. 2007. "Physiochemical and Properties of a Beverage Prepared from Pineapple and Soursop Juice Blends.” J. Nutr. Sci. 28: 201-8.

[18] Locket, T. C., Calvet, C. C., Griveti, E. L. 2000. “Energy 
and Micro-nutrients Composition of Dietary and Medicinal Wild Plant Consumed during Drought. Study of Rural Fulani North-Eastern Nigeria.” Int. J. Food Sci. Nutr. 51: 57.

[19] Adepoju, O. T., and Adeniji, P. O. 2008. "Nutrient Composition, Anti-nutritional Factors and Contribution of Native Pear (Deceyoides edulis) Pulp to Nutrient Intake of Consumers.” Nig. J. Nutr. Sci. 29: 15-21.

[20] Nwokocha, L. N., and Akobundu, E. N. T. 2013. "Nutrient Composition, Physical and Sensory Properties of Orange, Pineapple and Water Melon Juice.” Nig. J. Sci. 34: 147-50.

[21] Nelson, S. C. 2006. Morinda citrifolia. University of Hawaii, Manoa, College of Tropical Agriculture and Human Resources. Accessed March 21, 2017. https://www.Ctahr.Hawaii.Edu/Noni/Fruit_Juices.Asp.

[22] Manjula, S. N., Kengariora, M., and Ali, M. 2016. "Health Benefits of Morinda citrifola (Noni): A Review.” Pharmalognosy Journal 8 (4): 321-33.

[23] Johnson, J. I., Iwang, E. U., Hemen, J. I., Odey, M. O., Effong, E. E., and Eteng, O. E. 2012. "Evaluation of Anti-nutrient Contents of Water Melon (Citrullus lanatus).” Annual of Biological Research 3 (11):5145-50.
[24] FAO/WHO. 1991. Joint FAO/WHO Food Standard Programmes. Int. Codex Alimentarius Commission, xii (Suppl. 4), Rome.

[25] Peerzada, N., Renaud, S., and Ryan, P. 1990. "Vitamin C and Elemental Composition of Some Bush Fruits." Journal of Plant Nutrition 13: 787-93.

[26] Rakipov, N. 1987. Biochimie des culture tropicales. Moscou, Russie.

[27] Shovic, A. C., and Whistler, W. A. 2001. "Food Sources of Provitamin A and Vitamin C in the American Pacific." Trop. Sci. 41:199-202.

[28] Chuhieng, T., Hay, L., and Montet, D. 2005. “Detailed Study of the Juice Composition of Noni (Morinda citrifolia) Fruits from Cambodia.” Fruits 60: 13-24.

[29] Morton, J. F. 1992. "The Ocean-Going Noni, or Indian Mulberry (Morinda citrifolia)" Economic Botany 46: 241-56.

[30] Alais, C., and Linden, G. 1994. Biochimie alimentaire. Masson, Paris, France.

[31] Sarah, M. C., and Savage, P. G. 1999. “Oxalate Content of Foods and Its Effect on Humans.” Accessed May 6, 2018. https://www.researchgate.net/publication/259606309.

[32] Andrews, R. 2013. Phytates and Phytic Acid. 